\title{
Quality evaluation of DNA obtained from stored human saliva and its applicability to identification in Forensic Dentistry
}

\author{
Avaliação da qualidade do DNA extraído de saliva humana \\ armazenada e sua aplicabilidade na identificação em \\ Odontologia Legal
}

\begin{abstract}
Purpose: This study evaluated the quality of DNA obtained from stored human saliva and its applicability to human identification.

Methods: The saliva samples of 20 subjects, collected in the form of saliva in natura and from mouth swabs and stored at $-20^{\circ} \mathrm{C}$, were analyzed. After 7 days, the DNA was extracted from the 40 saliva samples and subjected to PCR and electrophoresis. After 180 days, the technique was repeated with the 20 swab samples.

Results: The first-stage results indicated that DNA was successfully extracted in $97.5 \%$ of reactions, $95 \%$ of saliva in natura and $100 \%$ of swab saliva samples, with no statistically significant difference between the forms of saliva. In the second phase, the result was positive for all 20 analyzed samples (100\%). Subsequently, in order to analyze the quality of the DNA obtained from human saliva, the SIX3-2 gene was tested on the 20 mouth swab samples, and the $\mathrm{PCR}$ products were digested using the $\mathrm{MbO} 1$ restriction enzyme to evaluate polymorphisms in the ADRA-2 gene, with positive results for most samples.
\end{abstract}

Conclusion: It was concluded that the quantity and quality of DNA from saliva and the techniques employed are adequate for forensic analysis of DNA.

Key words: Human identification; Forensic Dentistry; Forensic Medicine; DNA; molecular biology; saliva

\section{Resumo}

Objetivo: Este trabalho objetivou avaliar a qualidade do DNA obtido de saliva humana armazenada e sua aplicabilidade da identificação de pessoas.

Metodologia: Analisaram-se amostras salivares de $n=20$ sujeitos da pesquisa, coletadas nas formas de saliva in natura e de swab bucal, sendo armazenadas a $20^{\circ} \mathrm{C}$. Após 7 dias, o DNA foi extraído das 40 amostras de saliva e submetido à PCR e à eletroforese. Após 180 dias repetiu-se a técnica nas 20 amostras de swab.

Resultados: Os resultados da primeira etapa indicaram que o DNA foi extraído com sucesso em $97,5 \%$ das reações, e, analisando-se separadamente, em 95\% de saliva in natura e em $100 \%$ da saliva do swab, não havendo diferenças estatisticamente significantes entre as duas formas de saliva. Na segunda fase, o resultado foi positivo para as 20 amostras analisadas (100\%). Posteriormente, para analisar a qualidade do DNA obtido da saliva humana, o gene SIX3-2 foi testado nas 20 amostras de swab bucal e foi feita a digestão do produto da PCR com a enzima de restrição $\mathrm{MbO} 1$ para avaliar polimorfismo do gene ADRA-2 obtendo-se resultados positivos para a maioria das amostras.

Conclusão: Concluiu-se que a quantidade e a qualidade do DNA advindo de saliva e as técnicas empregadas estão adequadas à análise forense do DNA.

Palavras-chave: Identificação humana; Odontologia Legal; Medicina Legal; DNA; biologia molecular; saliva

\author{
Suzana Papile Maciel Carvalho a \\ Arsenio Sales-Peres ${ }^{b}$ \\ Lucilene Arilho Ribeiro-Bicudoc \\ Ricardo Henrique Alves da Silvad
}

- Doutorado em Odontologia Social, Universidade de São Paulo, São Paulo, SP, Brasil

b Faculdade de Odontologia de Bauru, Universidade de São Paulo, Bauru, SP, Brasil

c Hospital de Reabilitações de Anomalias Crâniofaciais de Bauru, Universidade de São Paulo, Bauru, SP, Brasil

d Faculdade de Odontologia de Ribeirão Preto, Universidade de São Paulo, Ribeirão Preto, SP, Brasil

Correspondence:

Suzana Papile Maciel Carvalho

Rua Christiano Pagani, 8-51, Apto. 61B, Vila Engler

Bauru, SP - Brasil

17047-144

E-mail: sumaciel@uol.com.br 


\section{Introduction}

Human identification is one of the most significant areas of study within Forensic Dentistry and Medicine. Both fields use the human body, in life or in various stages of postmortem (sliced, dilacerated, charred, macerated, decayed, in the process of skeletonization or already skeletonized), to establish human identification, which is essential for human relations, both at social and judicial levels (1).

Identification techniques using DNA have already been established as a robust process, with a high power of distinction and high reliability, accepted as legal proof in judicial cases such as paternity inclusion and exclusion and human identification (2). One of the main advantages of DNA use in forensic sciences lies in the fact that it can be extracted from different sources, such as blood samples, saliva, mouth mucosa cells (on cigarettes, envelopes, etc.), bone, teeth, tissues, organs, hair strands, semen, urine, feces, sweat, prints and other biological materials (3).

In most cases of genetic studies of families and populations, DNA is still obtained from blood. However, according to some authors $(4,5)$, the use of saliva and mouth swabs as sources of DNA shows some technical advantages over the use of blood. Collection is easier and painless, especially considering that it can be done on babies, children and elderly subjects, and does not have the religious implications of using blood. Also, there are higher potential risks of contamination when using blood, especially from hepatitis and AIDS, due to the use of sharp objects such as needles (5). Forensic studies have demonstrated that DNA analysis using the PCR of saliva deposited in prints, bite marks, cigarette butts, marks and prints left on stamps and other objects may help in individual identification (6-9).

The objective of this work was to evaluate the quality of DNA obtained from human saliva stored for two different periods, 7 and 180 days, and its applicability to the identification of individuals in forensic dentistry.

\section{Methodology}

This research was approved by the Research Ethics Committee of the Bauru School of Dentistry (no. 140/200) in accordance with the Brazilian Resolution 196/96 (10). The saliva sample was collected from patients and staff of both genders and various ages at the Bauru School of Dentistry (FOB-USP). Saliva was collected after informed consent forms were filled out. A total of 40 saliva samples were collected from 20 subjects, with each participant contributing two samples, one from saliva in natura and another using the single mouth swab technique.

\section{Saliva collection}

Saliva samples were collected using a sterile swab applied to the internal mouth mucosa and dried in a ventilated environment in the shade. Two milliliters of saliva in natura was collected without previous salivary stimulation but discarding the first saliva collection. These samples were stored in plastic microcentrifuge tubes and kept at $-20^{\circ} \mathrm{C}$.

\section{First Stage -7 days}

DNA Extraction

During this stage, in natura and swab saliva samples were analyzed. DNA extraction from saliva was conducted based on the technique documented by Umeda (11), modified by Sakai et al. (12), using InstaGene Matrix resin (Bio-Rad Laboratories Inc., Hercules, CA, USA).

\section{$P C R$ reactions for the $B$-actin gene}

For the PCR reaction, the study used the B-actin gene, whose amplified product is 351 base pairs (bp). This gene was chosen because it is exclusively human and frequently used in research. For the reaction, a mixture was prepared containing $5 \mu \mathrm{L}$ of DNA sample from saliva or swab, $5 \mu \mathrm{L}$ of PCR buffer (Gibco/BRL, Life Technologies, Inc., Gaithersburg, MD, USA), 1.25 units of Taq DNA Polymerase (Taq Promega ${ }^{\circledR}$, Promega Corporation, USA), $0.2 \mathrm{mM}$ deoxynucleotides (Invitrogen, USA), $0.4 \mu \mathrm{M}$ primer, and $1.5 \mathrm{mM}$ magnesium chloride (Gibco/BRL). The primer sequence used to amplify the B-actin gene is shown in Table 1. As a positive control, human DNA was used from blood collected from one of the researchers after filling out the informed consent form; for a negative control, water was used. The DNA concentration in the blood sample used as positive control was $220 \mu \mathrm{g} / \mathrm{mL}$.

Table 1. Sequence of primers used to amplify genes B-actin, SIX3-2 and ADRA-2A.

\begin{tabular}{cll}
\hline Gene & Direction & \multicolumn{1}{c}{ Sequence } \\
\hline B- Actin & Forward & AACCGCGAGAAGATGACCCAGATCATGTTT \\
& Reverse & AGCAGCCGTGGCCATCTCTTGCTCGAAGTC \\
SIX3-2 & Forward & TGGCGGGCCTCTGTGTCAGG \\
& Reverse & GTTGGGTATCCTGATTTCG \\
ADRA-2A & Forward & TCACACCGGAGGTTACTTCCCTCG \\
& Reverse & TCCGACGACAGCGCGCGAGTT \\
\hline
\end{tabular}

The samples were handled using gloves and masks in a sterile environment and for very brief periods at a time. The deionized water used in the PCR reactions was autoclaved, as were the other solutions, with the exception of the starters, dNTPs, buffer, and Taq DNA polymerase. In addition, the PCR reagents were mixed in a single tube and later added to the microcentrifuge tubes containing the individual DNA samples.

The thermal cycling conditions used for this pair of primers were as follows: $94^{\circ} \mathrm{C}$ for $2 \mathrm{~min}, 40$ cycles of $94^{\circ} \mathrm{C}$ for $45 \mathrm{~s}$, $58^{\circ} \mathrm{C}$ for $30 \mathrm{~s}$, and $72^{\circ} \mathrm{C}$ for $1.5 \mathrm{~min}$, followed by a final period at $72^{\circ} \mathrm{C}$ for $10 \mathrm{~min}$.

\section{Electrophoresis and PCR production detection}

PCR products ( $10 \mu \mathrm{L}$ from each amplified sample) were analyzed using horizontal electrophoresis in $2 \%$ agarose gel with a $100 \mathrm{~V}$ current for 1 hour. After electrophoresis, the agarose gel was photographed to record the presence 
of amplified products of anticipated sizes. The molecular weight of the PCR products was determined by comparison to a $100 \mathrm{bp}$ molecular weight marker (Amersham Pharmacia Biotech, England).

\section{Second Stage -180 days}

Only the $n=20$ saliva samples collected by mouth swab were analyzed because the results of the first stage did not show differences between the two collection methods and also because saliva collection using mouth swabs is more practical. The DNA extraction method was the same as that used in the first stage, as were the reagents and PCR conditions for the B-actin gene.

\section{$P C R$ reaction for the SIX3-2 gene}

In order to perfect the proposed analysis and due to the detection of a trace of agarose gel in the amplification of the human B-actin gene (a strong indicator that the extracted DNA could be of insufficient quality for forensic analysis), another human gene, SIX3-2, was used. Thus, it was possible to evaluate whether the problem was in the quality of the extracted DNA or in the amplification of the gene. Additionally, to test the same DNA after the PCR, the MbO1 restriction enzyme was used to analyze a polymorphism in the ADRA-2A gene.

The amplification of the SIX3-2 gene was performed in only 14 mouth swab saliva samples because the objective was only to verify the quality of extracted DNA. The DNA samples were quantified using a $\mathrm{GE}^{\circledR}$ spectrophotometer (General Electric, USA) and diluted to a final concentration of $20 \mathrm{ng} / \mathrm{mL}$. The amplification of SIX3-2 was performed in a $20 \mu \mathrm{L}$ volume containing genomic DNA (60 ng, $2.0 \mu \mathrm{L})$, dNTPs $(100 \mu \mathrm{M}, 0.3 \mu \mathrm{L})$, primers $(25$ pmol each, $0.4 \mu \mathrm{L}$ each) and Taq polymerase $(5 \mathrm{U}, 0.3 \mu \mathrm{L})$. The PCR Enhancer Kit (Invitrogen, Canada), consisting of 10X buffer $(2.0 \mu \mathrm{L}), \mathrm{MgSO} 4(0.6 \mu \mathrm{L})$ and enhancer solution $(1.0 \mu \mathrm{L})$, was used in the reactions. The sequences of primers used in the amplification of gene SIX3-2 can be found in Table 1.

The thermal cycling conditions used for this pair of primers were as follows: $94^{\circ} \mathrm{C}$ for $4 \mathrm{~min}, 40$ cycles of $94^{\circ} \mathrm{C}$ for $30 \mathrm{~s}$, $56^{\circ} \mathrm{C}$ for $30 \mathrm{~s}, 72^{\circ} \mathrm{C}$ for $1.0 \mathrm{~min}$, followed by a final period of $72^{\circ} \mathrm{C}$ for $7 \mathrm{~min}$. Electrophoresis was conducted as described above, with an amplified product of $374 \mathrm{bp}$.

Digestion using Mb01 restriction enzyme for analysis of an ADRA-2A gene polymorphism

Because the objective of this procedure was to analyze the quality of the DNA obtained in analyses after PCR, only 8 samples were subjected to digestion for $2 \mathrm{~h}$ using the $\mathrm{MbO} 1$ restriction enzyme. Samples 1, 2, 5, 6, 8, 10, 12 and 14 were selected. The reagents used were PCR product $(15.0 \mu \mathrm{L})$, $\mathrm{H} 2 \mathrm{O}(5.5 \mu \mathrm{L})$, enzyme buffer $(2.5 \mu \mathrm{L})$, restriction enzyme $(2.0 \mu \mathrm{L})$, and oil $(1 \mathrm{drop})$ at $37^{\circ} \mathrm{C}$. Digestion with the $\mathrm{MbO} 1$ enzyme resulted in four constant fragments $(5,62$, 116 and $165 \mathrm{bp}$ ). The sequences of primers used for PCR before the digestion of the ADRA-2A gene are displayed in Table 1.

\section{Statistical Analysis}

Data were analyzed with the McNemar test at a $5 \%$ significance level using the SAS software 9.1 (SAS Institute Inc., Cary, NC, USA).

\section{Results}

First stage -7 days (Table 2)

All in natura and mouth swab saliva samples were subjected to DNA extraction and PCR, and DNA extraction and PCR were achieved in $97.5 \%$ of the samples (Table 3). There were no statistically significant differences found between the types of saliva collection $(P=0.289)$. Also, there was no concurrence between the responses for samples from the same individual, i.e., when the response was negative for one type of sample (saliva in natura or from mouth swab), it was positive for the other from the same individual.

Table 2. DNA Concentration $(\mu \mathrm{g} / \mathrm{mL})$ obtained from each sample of saliva in natura and from mouth swab, analyzed after 7 days of storage (1 st stage).

\begin{tabular}{|c|c|c|}
\hline Sample number & $\begin{array}{c}\text { DNA concentration } \\
\text { - saliva in natura } \\
(\mu \mathrm{g} / \mathrm{mL})\end{array}$ & $\begin{array}{c}\text { DNA concentration } \\
\text { - mouth swab saliva } \\
(\mu \mathrm{g} / \mathrm{mL})\end{array}$ \\
\hline 1 & 268 & 442 \\
\hline 2 & 188 & 130 \\
\hline 3 & 232 & 615 \\
\hline 4 & 300 & 82 \\
\hline 5 & 218 & 195 \\
\hline 6 & 199 & 183 \\
\hline 7 & 253 & 238 \\
\hline 8 & 455 & 238 \\
\hline 9 & 340 & 240 \\
\hline 10 & 198 & 240 \\
\hline 11 & 205 & 238 \\
\hline 12 & 314 & 345 \\
\hline 13 & 232 & 425 \\
\hline 14 & 448 & 272 \\
\hline 15 & 197 & 482 \\
\hline 16 & 276 & 505 \\
\hline 17 & 310 & 338 \\
\hline 18 & 405 & 555 \\
\hline 19 & 269 & 430 \\
\hline 20 & 201 & 298 \\
\hline
\end{tabular}

Table 3. Frequency distribution of positive and negative reactions to DNA extraction and PCR for samples of human saliva.

\begin{tabular}{lll}
\hline & $\begin{array}{c}\text { Positive } \\
\text { N (\%) }\end{array}$ & $\begin{array}{c}\text { Negative } \\
\text { N (\%) }\end{array}$ \\
\hline Saliva in natura & $19(95 \%)$ & $1(5 \%)$ \\
Saliva from swab & $20(100 \%)$ & $0(0 \%)$ \\
TOTAL & $39(97.5 \%)$ & $1(2.5 \%)$ \\
\hline
\end{tabular}




\section{Second Stage -180 days (Table 4)}

\section{B-actin gene amplification}

The amplification of the B-actin gene was possible in all 20 $(100 \%)$ samples of saliva collected via mouth swab analyzed after 180 days of storage (Fig. 1 and 2).

\section{SIX3-2 gene amplification}

Of the 14 samples selected for SIX3-2 gene amplification, the results indicated a positive amplification for 12 samples $(86 \%)$, which shows that the DNA has the quality required for molecular analysis (Fig. 3 and 4).

\section{Digestion with Mb01 restriction enzyme}

The results showed that all selected samples $(n=8)$ were successfully digested with the restriction enzyme, which confirms that the extracted DNA has the quality required for forensic analysis (Fig. 5).

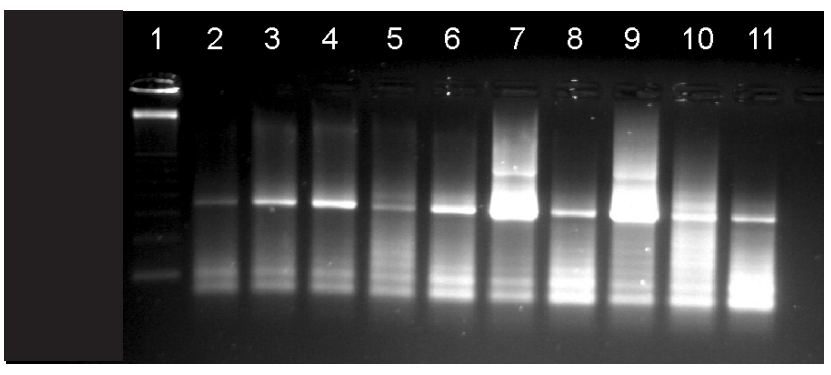

Fig. 1. PCR pattern obtained in mouth swab saliva samples. $2 \%$ agarose gel stained with ethidium bromide. Column 1, molecular weight marker for $100 \mathrm{bp}$; columns $2-11$, mouth swab saliva DNA samples (samples: 1, 2, 3, 4, 5, 6, 7, 8, 9, 10).

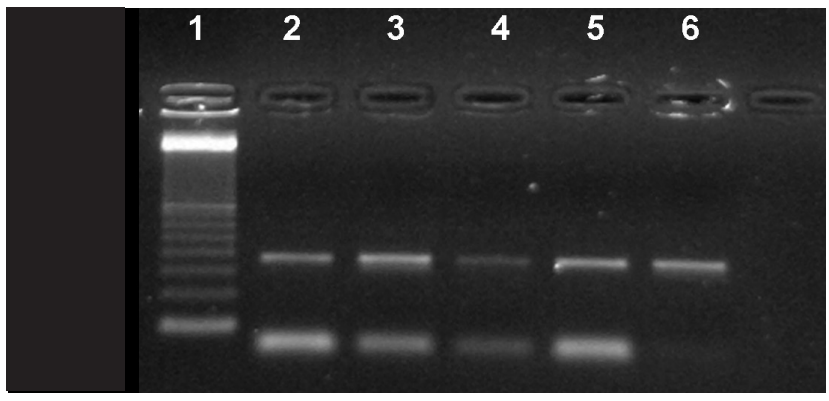

Fig. 3. PCR pattern obtained for the amplification of gene SIX3-2. $2 \%$ agarose gel stained with ethidium bromide. Column 1 , molecular weight marker for 100 bp; columns 2-6, samples of PCR products of mouth swab saliva (samples: 1, 2, 4, 5, 6).
Table 4. DNA Concentration $(\mu \mathrm{g} / \mathrm{mL})$ obtained from each sample of saliva in natura and from mouth swab, analyzed after 180 days of storage (2nd stage).

\begin{tabular}{cccc}
\hline Sample & $\begin{array}{c}\text { DNA } \\
\text { concentration } \\
(\mu \mathrm{g} / \mathrm{ml})\end{array}$ & Sample & $\begin{array}{c}\text { DNA } \\
\text { concentration } \\
(\mu \mathrm{g} / \mathrm{ml})\end{array}$ \\
\hline 1 & 138 & 11 & 270 \\
2 & 145 & 12 & 173 \\
3 & 140 & 13 & 200 \\
4 & 88 & 14 & 365 \\
5 & 102 & 15 & 352 \\
6 & 140 & 16 & 230 \\
7 & 135 & 17 & 528 \\
8 & 140 & 18 & 338 \\
9 & 170 & 19 & 340 \\
10 & 165 & 20 & 285 \\
\hline
\end{tabular}

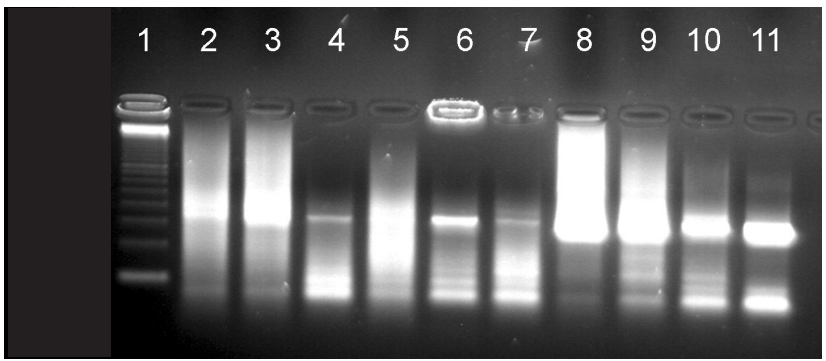

Fig. 2. PCR pattern obtained in mouth swab saliva samples. $2 \%$ agarose gel stained with ethidium bromide. Column 1, molecular weight marker for $100 \mathrm{bp}$; columns 2-11, mouth swab saliva DNA samples (samples: 11, 12, 13, 14, 15, 16, 17, 18, 19, 20).

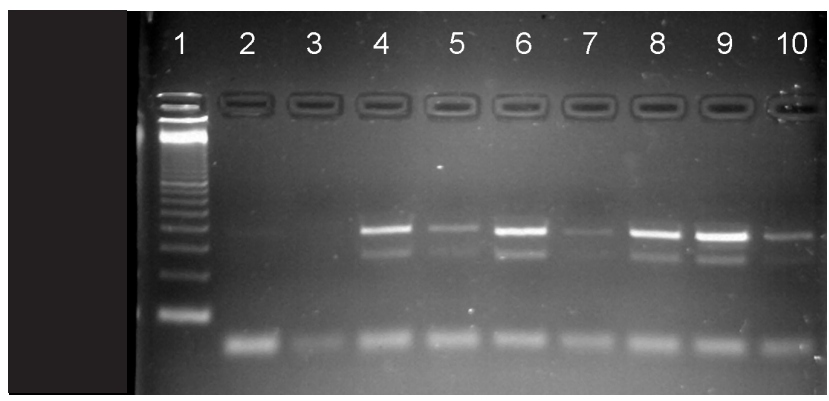

Fig. 4. PCR pattern obtained for the amplification of gene SIX3-2. $2 \%$ agarose gel stained with ethidium bromide. Column 1, molecular weight marker for $100 \mathrm{bp}$; columns 2-10, samples of PCR products of mouth swab saliva $(3,7,8,9,10,11,12,14)$.

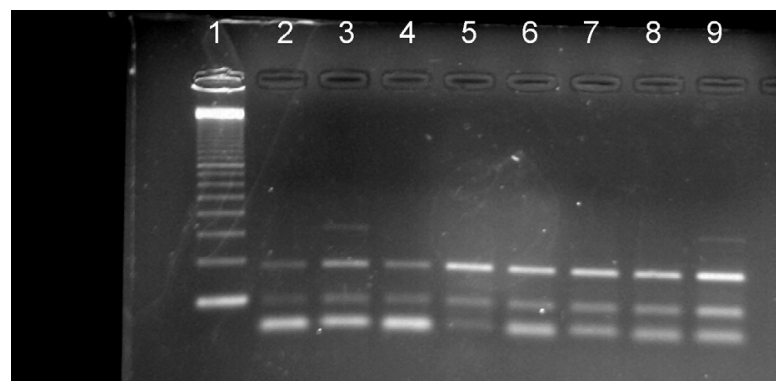

Fig. 5. Pattern obtained after the digestion of mouth swab saliva samples with $\mathrm{MbO} 1$ enzyme for polymorphism of gene ADRA-2. Column 1, molecular weight marker for $100 \mathrm{bp}$; columns 2-9, samples $(1,2,5,6,8,10,12,14)$. 


\section{Discussion}

The biological material found at the crime scene or collected from cadavers and mortal remains, present either in the victim's body or on objects, often is scarce or degraded $(13,14)$. There is concern regarding the preservation of biological samples for DNA extraction and analysis, and these procedures are specified in the existing rules (13-16). Contamination by external DNA was vigilantly avoided in this study because it would hinder or even make impossible the extraction of the relevant DNA, especially because the use of PCR techniques enables the amplification of even a single DNA molecule, however degraded it may be (17). This single molecule, by contaminating the biological samples, could compromise the analysis of the genetic profile and consequently make the individual's identification impossible. If the contaminating DNA is present in comparable levels to the target DNA, its amplification could confuse the interpretation of the typing results. Whenever saliva is used as a source of DNA, such a risk of contamination by foreign DNA must be considered due to the ease of contact with other materials through the mouth.

INTERPOL rules (14) cite that constant freezing and thawing of samples can degrade the DNA. Therefore, care was taken to store the mouth swabs containing saliva in two microcentrifuge tubes, so they could be frozen at $-20^{\circ} \mathrm{C}$ until use, each tube for a separate experimental stage.

Controls were used to aid in the detection of contaminants. In the case of the negative controls (water), the desired amplification did not occur; for the positive controls, the amplification was identical to that obtained with human saliva, indicating the absence of contamination and proving its condition as human DNA. Thus, it can be affirmed that human saliva is a reliable and alternative source for DNA extraction compared to blood as reported previously $(4,5,18)$.

Moreover, saliva-derived PCR is based on repeated rinsing and centrifuging (11). The main objectives of these measures are to remove possible PCR inhibitors, such as phenol, protease $\mathrm{K}$, excess chelating agents, hemoglobin and other red blood cell proteins, and high salt concentrations, and to allow a reduction in the detection limit of target cells. This protocol was properly followed, with rinsing and centrifuging repeated four times, as per the instructions of the above-mentioned author.

Considering that saliva - a biological material - may contain PCR-inhibiting molecules, it became necessary to use a commercial DNA purification matrix, even after repeated rinsing and centrifuging, because inhibition would not be overcome by an increase in the amount of primers or in the amount of DNA in the PCR reaction. These increases would also introduce more inhibitors into the reaction. The matrix is able to chelate bivalent ions, favoring the efficiency of DNA extraction and protecting the DNA at high temperatures (19). Thus, the Chelex 100 (Bio-Rad Laboratories, Inc., Hercules, CA, USA) or InstaGene Matrix (Bio-Rad Laboratories, Inc., Hercules, CA, USA) resins could be used. However, studies on the use of Chelex 100 for DNA extraction resulted in weak and poorly visible bands for the sought targets $(11,12,19)$. As such, InstaGene Matrix was used according to the manufacturer's instructions, with positive results.

Whenever the topic of biological material storage is discussed, specifically in this context of human saliva, there are questions regarding whether degradation of the material would occur over time. Previous studies showed that saliva could be stored without undergoing changes $(4,18)$. Those works achieved very promising results with the use of saliva in molecular biology because specific products of the correct size were obtained for all samples, even under different less-than-ideal storage conditions. Some authors obtained the same band patterns for the same individuals from saliva stains in mouth gags, envelopes and swabs, fresh saliva, blood, saliva from bite marks and skin $(20,21)$, saliva stains $(6)$, fresh saliva or in natura $(4,18)$ from stamps and letters (22) and from foods, such as cheese (9).

This work evaluated the durability of saliva when stored for the periods of 7 and 180 days. The first period was defined according to the end of saliva collection, which totaled six days, and the second period (180 days) was established according to the literature $(4,18)$ and the deadline for issuing the results. In the first stage of this research, human DNA extraction was possible in $97.5 \%$ of samples, whereas in the second stage, extraction was possible in $100 \%$ of cases. This supports the possibility of storing human saliva without the risk of changes to it or its DNA for at least 180 days prior to its use for genetic material extraction. This strengthens the conclusion that, if degradation of stored material occurs, it does not diminish the quality of the material for later molecular biology analyses.

The results of the first stage of this study showed no statistically significant differences between the two methods of saliva collection. Furthermore, when detection of a target gene was not possible in a given sample, it was possible to amplify the target gene from the other sample of the same individual. In other words, when the expected band pattern was not obtained for a sample of saliva in natura, the pattern was observed in the mouth swab sample from the same individual, and vice versa. Therefore, for the second stage, it was decided only to repeat the DNA analysis reactions in saliva from mouth swabs, due to the fact that swab collection is easier compared to saliva in natura. The results of this second phase confirmed the possibility of using human saliva for identification because most samples responded positively, both in PCR reactions and in digestion with the $\mathrm{MbO1}$ restriction enzyme.

The use of different genes occurred due to questions regarding the quality of the DNA extracted from amplification of the B-actin gene because the gel showed a stain that could indicate a problem in the amplification or low quality of the extracted DNA, which was the focal issue of the study. Therefore, in addition to B-actin, the SIX3-2 gene was used as well for its proven track record in the lab, featuring a well defined application protocol, with the objective of analyzing 
the quality of the DNA for forensic comparison. With that same purpose, digestion using the Mb01 restriction enzyme was applied. The results indicated good qualitative use of the DNA extracted from human saliva in both analysis periods (7 and 180 days).

\section{Conclusions}

These results showed that the quantity and quality of DNA from saliva, even after a period in storage, and the techniques employed are adequate for forensic DNA analysis.

\section{References}

1. Oliveira RN, Daruge E, Galvão LCC, Tumang AJ. Contribuição da odontologia legal para a identificação post-mortem. Rev Bras Odontol 1998;55:117-22.

2. Silva RHA, Oliveira RN. Odontologia legal e a busca pela identidade humana [Internet]. 2006. [cited 2006 Dez 20]. Availabe from: http://www.jornaldosite.com.br.

3. Remualdo VR, Oliveira RN. Potencial de análise forense do DNA de diferentes amostras biológicas. Rev Assoc Paul Cir Dent 2005;59:421-52.

4. Schie RCAA van, Wilson ME. Saliva: a convenient source of DNA for analysis of bi-allelic polymorphisms of FC gamma receptor IIA (CD32) and Fc gamma receptor IIIB (CD16). J Immunol Methodos 1997;208:91-101.

5. Trevillato PC, Line SR. Use of buccal epithelial cell for PCR amplification of large DNA fragments. J Forensic Odontostomatol 2000; 18:6-9.

6. Yamamoto $\mathrm{Y}$, Ishizu H. Km genotyping by polymerase chain reaction (PCR) using allele-specific amplification primers. Forensic Sci Int 1995; 75:85-93.

7. Sweet $D$, Dizzino JA. Personal identification through dental evidence - tooth fragments to DNA. J Calif Dent Assoc 1996;24:35-42.

8. Hochmeister MN, Rudin O, Ambach E. PCR analysis from cigarette butts, postage stamps, envelope sealing flaps and others salivastained material. In: Lincooln PJ, Thomson J, editors. Forensic DNA profiling protocols. Totowa: Humana Press; 1998. p.27-32. (Methods in molecular biology, n. 98).

9. Sweet D, Hildebrand D. Recovery of DNA from human teeth by cryogenic grinding. J Forensic Sci 1998;43:1 199-202.

10. Brasil. Conselho Nacional de Saúde. Resolução n 196, de 10 de Outubro de 1996. Aprova as diretrizes e normas regulamentadoras de pesquisas envolvendo seres humanos. [internet]. 1996. [cited $2007 \mathrm{Fev}$ 10]. Available from: http://conselho.saude.gov.br/ resolucoes/reso_96.htm

11. Umeda M. The utility of whole saliva to detect the oral presence of periodontopathic bacteria. J. Periodontol 1998;69:828-33.

12. Sakai VT, Campos MR, Machado MA, Lauris JR, Greene AS, Santos CF. Prevalence of four putative periodontopathic bacteria in saliva of a group of Brazilian children with mixed dentition: 1 -year longitudinal study. Int J Paediatr Dent 2007;17:192-9.

13. Federal Bureau of Investigation. Quality assurance audit for forensis DNA and convicted offender DNA databasing laboratories. Forensic Sci Commun [serial on the internet]. 2001. [cited 2001 Sep 28] Available from: http://www.fbi.gov/hq/lab/fsc/backissu/jan2001/ dnaaudit.htm

14. Internacional Criminal Police Organization. INTERPOL handbook on DNA data exchange and practice. [handbook online]. 2001. [cited 2002 Mar 01]. Available from: http://www.interpol.int/Public/ Forensic/dna/HandbookPublic.pdf

15. São Paulo (Estado). Secretaria de Segurança Pública de São Paulo. Resolução SSP-194 de 02 de junho de 1999. Diário Oficial do Estado. 1999 Jun 3: Seção 1:104.

16. Federal Bureau of Investigation. Handbook of forensic services: evidence examinations- DNA general [handbook online]. 1999. [cited 2008 May 10]. Available from: http://www.fbi.gov/hq/lab/ handbook/exasdna.htm

17. Strachan T, Read A. Genética molecular humana. 2. ed. Porto Alegre: Artmed; 2002.

18. Ng DP, Koh D, Choo SG, Ng V, Fu Q. Effect of storage conditions on the extraction of PCR-quality genomic DNA from saliva. Clin Chim Acta 2004; 343:191-4.

19. Mätto J, Saarela M, Alaluusua S, Oja V, Jousimies-Somer H, Asikainen S. Detection of Porphyromonas gingivalis from saliva by PCR by using a simple sample-processing method. J. Clin. Microbiol 1998;36:157-60.

20. Rahimi M, Heng NC, Kieser JA, Tompkins GR. Genotypic comparison of bacteria recovered from human bite marks and teeth using arbitrarily primed PCR. J Appl Microbiol 2005;99: 1265-70.

21. Anzai EK. Extração de DNA de saliva humana depositada sobre a pele e sua aplicabilidade aos processos de identificação individual. [dissertation]. São Paulo (SP): Faculdade de Odontologia, Universidade de São Paulo; 2002.

22. Allen M, Saldeen T, Gyllensten U. PCR- Based DNA typing of saliva on stamps and envelopes. Biotechniques 1994;17:546-52. 